\title{
Remaking Life in Transnational Urban Space: Zimbabwean Migrant Teachers in Manzini, Swaziland
}

DOI: $10.11567 /$ met.30.2.2

UDK: 371.12-054.62(684:688.7)

331.556.44(684:688.7)

Prethodno priopćenje

Primljeno: 1.9.2014.

Prihvaćeno: 18.10.2014.

\section{Daniel Tevera}

Department of Geography and Environmental Studies, University of the Western Cape, Bellville

dtevera@uwc.ac.za

\begin{abstract}
SUMMARY
Recent academic debate on the transnationalised lives of skilled migrants from developing countries tends to provide universalizing explanations that often fail to address the underlying socio-economic contexts. This paper aims to contribute to the debate by exploring how skilled migrants in South-South diasporic situations remake their livelihood strategies and expectations as they operate in transnational spaces. The paper is based on field research involving in-depth interviews with Zimbabwean migrant teachers living in Manzini, the commercial hub of Swaziland. The study provides insights into the complicated and transnationalised adjustment strategies pursued by migrants as they grapple with challenges around inclusion and exclusion in the host country and the maintenance of a "virtual presence" in Zimbabwe, their home country through the internet, Skype, mobile phones and remittance flows.
\end{abstract}

KEY WORDS: transnationalism, virtual presence, inclusion, exclusion, remaking xenophobia, migrants, Manzini

\section{INTRODUCTION}

Narratives of "transnationalism" highlight how migrants engage in lives across borders while simultaneously maintaining social and economic ties to home. ${ }^{1}$ Recent narratives of transnationalism and trans-national movements between Zimbabwe and its neighbours focus on the "back and forth" human flows of professionals between Zimbabwe and host countries, espe-

The term "transnational" helps to describe the way that immigrants "live their lives across borders and maintain their ties to home, even when their countries of origin and settlement are geographically distant" (Glick Schiller, Basch and Blanc-Szanton, 1992). 
cially South Africa, Botswana, Swaziland, Namibia and Lesotho. ${ }^{2}$ The narratives help to improve our spatial understandings of both the specificities and the boundedness of the "here" and "there" that characterize migrant "host space" and "home space". The study provides insights into how, in recent years, Zimbabwean migrant teachers have forged "transient-roots" in fluid and shifting spaces. Viewing the Zimbabwean migrant teachers through such a "transnational lens" makes it possible to conceptualize the mobility of skilled people in spatial and ideational terms that embrace both those who travel to host spaces and those who remain in home spaces. ${ }^{3}$

Migrant transnationalism is the process by which transmigrants create and maintain multiple socio-economic relations that make it possible for them to maintain a virtual presence in their home country while simultaneously negotiating "citizenship rights" in spaces where their "otherness" is invariably used to deny them access to employment opportunities and public infrastructure such as housing (Bailey, 2001; Conradson and Latham, 2005; Kriger, 2010; Worby, 2010). Blunt (2007) reminds us how mobility, transnationalism and diaspora all intersect in a manner which enables us to examine migration and urbanism from new perspectives. In southern Africa, the internet has played a crucial role in mediating transnational urbanism through which the continuity of interrelationships between home and host country is sustained.

During the past decade debates on conceptualizing transnationalism (Portes, Guarnizo and Landolt, 1999; Portes, 2003; Kivisto, 2001; Nolin, 2002) have explored the various dimensions of interconnecting ties that migrants have with their home and host countries. While the scholarly works of Boyd (1989) and Faist (2000) offer some conceptual clarification on the transnationalism concept, these studies have shown that a transnational perspective would not necessarily provide an adequate account for the migration of skilled people from one country to another. Several studies done in southern Africa reveal that a multidimensionality of causal processes (including economic, social, political and environmental factors) explain why people would uproot themselves from their families and friends in order to settle in new foreign spaces (Adepoju, 2006; Campbell, 2001; Crush and Tevera,

2 For long, the economically strong economies of South Africa and Botswana have made these two countries the preferred destinations of regional migration flows of skilled people across southern Africa.

3 Skilled migration has emerged as one of the predominant types of population movements in southern Africa (Crush and Tevera, 2010b). In some ways, transnationalism has become a multi-layered concept that refers to various aspects of migrant experiences ranging from the material to symbolic and imagined. 
2010b; Tevera, 2011; Tevera and Crush, 2010; Manik, 2009; Oucho, 2000). Adepoju (2006) argues that economic, social, political and environmental conditions are key variables that account for the contemporary international migration patterns in sub-Saharan Africa. However, some scholars have argued that the decision to migrate is quite complex as each migration movement is a personal response to issues around structure and agency. In line with this logic, Silvey and Lawson (1999) and Lawson (2000) argue for the need for ethnographic accounts that capture voices and viewpoints of migrants so as to provide an important counterpoint to the grand narratives of mobility. Recent academic debate on the transnationalised lives of skilled migrants from developing countries tends to provide universalizing explanations that often grapple to address the underlying socio-economic contexts (Al-Ali, Black and Koser, 2001; Kelly and Lusis, 2006; Landolt, 2001; Silvey, 2006; Levitt, Dewind and Vertovec, 2003).

This paper aims to contribute to the academic debate by exploring how skilled migrants in South-South diasporic situations remake their livelihood strategies and expectations as they occupy transnational spaces and often find themselves confronting socio-spatial urban challenges around issues of identity, inclusion and exclusion. The study specifically provides insights into the complicated and transnationalised adjustment strategies pursued by Zimbawean migrant teachers as they respond to challenges around belonging in the host country and the maintenance of a "virtual presence" back, through internet links, emails, Skype connections and remittance flows. The paper is based on a rich literature on South-South migration of skilled African migrants. It is also based on field research that was conducted in 2012 and which involved in-depth interviews with 12 Zimbabwean migrant teachers based in Manzini, the commercial capital of Swaziland.

\section{METHODOLOGY}

The paper is based on qualitative, in-depth semi-structured interviews conducted with 12 Zimbabwean migrant teachers in Manzini. Ethical issues were followed by asking for permission to interview and observe the participants and explaining to them what the study was all about and that they had every right to stop participating in the interview at any time if they felt uncomfortable. The confidentiality and anonymity of participants was ensured by keeping the responses confidential through the use of fictitious names that were used in this paper in order to protect the identities of the Zimbabwean migrant teachers who were interviewed. 
The interviews were carried out by the author, with the help of a research assistant, between January and September 2012, mostly in the homes of the migrant teachers. This made it possible to make observations on the living conditions of the teachers and the extent to which they had become part of the "socio-cultural texture" of the city of Manzini. The Zimbabwean migrant teachers who participated in the in-depth interviews were selected using the snowball sampling technique whereby the first Zimbabwean migrant teacher interviewed was asked to recommend a Zimbabwean teacher to interview. Most participants were willing to recommend at least one possible participant to interview and as a result, the pool of participants was wide. It became possible to interview a fairly diverse group in terms of demographic profile, socio-economic background, and length of period of stay in Swaziland. Interviews lasted between one to two hours and each of the participants had two interview sessions. The first session focused on the push factors back home that compelled the Zimbabwean teachers to leave their country. It also focused on the pull factors that attracted the Zimbabwean teachers to Swaziland which is a small country with a population of just over a million. The second session focused on the work and social experiences of the Zimbabwean migrant teachers since settling in Manzini. The specific themes covered during both sessions included the migration triggers that made the teachers leave their jobs back home in Zimbabwe; migration experiences; personal work histories in Swaziland; an assessment of past and current employment conditions; social networks; and generally how they imagined and re-imagined the Manzini urban space. ${ }^{4}$ All the interviews were recorded and transcribed before analysis.

The general profile of the Zimbabwean migrant teachers in the study shows considerable diversity: seven were men and five were women; all were living in the country legally but it was not possible to verify whether they all had work permits; their ages ranged from 27 to 50 years; all were well-educated, with most having been educated at schools and universities in Zimbabwe. They had lived in the Swaziland for at least two years; two had master's degrees, eight had bachelor's degrees and two had diplomas in education; on average it took them 1-2 years to get employment as teachers after arriving in Swaziland. They worked at private colleges/schools and government schools in and around the city of Manzini. Some were supplementing their incomes by performing odd jobs during weekends as hair-

4 Manzini city is the commercial hub of Swaziland and its population of about 70,000 consists of 31,380 residing within the city municipal boundary and an additional 38,620 residing in the peri-urban areas. 
dressers, landscapers and operators of utility vehicles that delivered remittances, in the form of cash and goods, to Zimbabwe every fortnight.

\section{MIGRATION EXPERIENCES OF ZIMBABWEAN TEACHERS IN MANZINI}

Manzini is a typical post-colonial city with its well known challenges ranging from inadequate housing, unplanned settlements, poverty, inequality and a desperate search for identity. Like all post-colonial cities, Manzini is an urban space that is struggling to hybridize new ethnicities, new cultures and social classes. The diverse and vibrant African diasporic communities in the city include Zimbabweans, Batswana, Basotho, Swazi, Somalis, Nigerians, Senegalese and Congolese. Zimbabwean migrant teachers are one of the largest groups of foreign skilled workers employed by government and the private sector in Swaziland. Most of the teachers prefer to reside in the major cities, such as Mbabane, Manzini and Matsapha, because this is where the jobs are and also because these urban centres have fairly large migrant communities with well established informal social networks that provide a nurturing environment to new migrants. An enduring legacy of international migration in southern Africa has been the growth of multicultural urban scapes where nationals and migrants compete for jobs and social services. As a result, there has been a hardening of anti-migrant views and xenophobic attacks especially in countries like South Africa, Botswana and Namibia, which are the leading migrant receiving countries in the southern Africa region (Tevera, 2013; Morapedi, 2007; Morris, 1998). The xenophobic conflicts are both about economic struggles between competing local and foreign business people but they are also a manifestation of intolerance of diversity in the growing multicultural cities. ${ }^{5}$ It is worth noting that in most urban spaces, foreign migrant communities remain largely unassimilated and excluded, and this raises major issues surrounding the notions of belonging and citizenship under conditions of multicultural urbanism (Smith, 2001; Tevera, 2013).

5 The term xenophobia involves negative social representations and practices that discriminate against immigrants, refugees and migrants. As Tevera (2013) observes, xenophobia, and its various forms of intolerance and violence, is a source of concern because it generates rhetoric that at times provides moral justification for the exclusion of non-nationals from accessing basic services that they may be entitled to, such as public health and education, shelter and potable water sanitation. According to Manik (2013) there is evidence of xenophobic behaviour in some South African schools which has created a sense of social and professional disconnection on the part of immigrant teachers. 
A weak national economy and political violence are the main migration triggers that have directed the flow of migrants from Zimbabwe to neighbouring countries and elsewhere (Crush and Tevera, 2010a; Tevera and Crush, 2010; Hammar, McGregor and Landau, 2010; Kriger, 2010). Migration to Swaziland and to Manzini in particular represented an escape from economic hardship. The vast majority of Zimbabwean migrant teachers in the current research were fleeing or leaving some form of unsatisfactory situation (Crush and Tevera, 2010b; Tevera and Crush, 2010). While the vast majority of people had some form of employment or business in their home countries, these were often precarious or badly paid or involved working long hours.

The section below highlights the experiences of four Zimbabwean migrant teachers who were part of the 12 that were interviewed. ${ }^{6}$ These four specifically agreed to have their profiles appear in any academic related publications while the other eight were reluctant to do so. One participant pointed out that: "Manzini was a small place [...] any dishing out of information about my age, my personal circumstances and what I teach would expose me because there are not too many Zimbabwean teachers who teach mathematics at school $\mathrm{X}$ in area $\mathrm{Y}^{\prime \prime}$.

\section{Case 1: Sibongile}

Sibongile was 32 years old and a single parent living with her mother and her 12 year son and she had migrated to Swaziland in 2008, at the height of the economic crisis in Zimbabwe. She stayed in a low income suburb of Manzini and she taught at a private secondary school in the peri-urban zone of Manzini which is about $10 \mathrm{~km}$ from where she resided and she had to catch a public taxi to work and back home from Monday to Friday. Back home in Zimbabwe, Sibongile used to work as a teacher at a government secondary school in one of the high density (low income) suburbs of Bulawayo. The classes were large and the teaching load was high because some of the teachers had left the school for greener pastures in South Africa and had not been replaced. Her salary back home in Zimbabwe was low and she had problems paying her bills.

Sibongile appeared to be satisfied with her life in Manzini. Her full time contract position as a Home Economics teacher in Manzini gave her an adequate salary that took care of her monthly bills and also made it possible for her to remit some money every month to her mother back in Zimbabwe.

6 The number of Zimbabwean migrant teachers in Manzini is between 45-60 people and this is a small percentage of the total Zimbabwean migrant population in the city. 
Through her locally and transnationally interconnecting networks, she found Manzini to be a vibrant and inclusive city that offered various opportunities. However, she remembered how she became depressed when it took her more than three months to get a work permit and she had to travel back to Zimbabwe in order to regularise her stay in the country. However, at the time of the interviews her concerns were a housing project back home and the renewal of her contract during the coming months. Sibongile was excited about the house she was building back home in one of the middle income suburbs of Bulawayo and had been thinking about looking for a teaching position in Johannesburg, South Africa which is much closer to her home in Bulawayo than Manzini. Sibongile always talked about the day when she would finally retire and return home to be with her people. However, she said "[...] for now I am happy to keep contact via emails, Skype connections, remittance flows and the annual Christmas holiday visit".

\section{Case 2: Tatenda}

The case of Tatenda, who was 48 years, was different. He had stayed in Swaziland for more than eight years and was married to Philile (a Swazi woman) who taught at the same school where he was teaching just outside Manzini. Financially and professionally he seemed to be doing well but during the in-depth interviews it became very clear that he had some very serious problems around issues of "not-belonging". Tatenda's livelihood strategies in Manzini embraced a perspective whereby identity, space and temporality were all rendered contingent, shifting and uncertain. He argued that being treated as "other" at the school where he taught made him feel excluded and unwanted. He pointed out during the interviews that "[...] social life in Manzini is good and everyone is friendly and helpful as long as you are not competing with them for jobs".

His latest efforts to become a Swazi citizen, was through the traditional kukhonta system and had been unsuccessful. ${ }^{7}$ Tatenda believes that his application was unsuccessful because he had not established firm roots in any of the rural communities. He said "[...] my years of stay in Manzini did not count at all; the chief asked me if I had a rural homestead in Swaziland and was tilling the land. Despite my marriage to Philile, the chief still considered me an outsider". Tatenda faced another challenge. He mentioned that his marriage was showing signs of stress and was heading towards a break down. Philile had complained during my second interview with the couple

Foreigners who have lived in Swaziland for extended periods can apply for citizenship through the traditional kukhonta system whereby they submit their application through their local chief. 
that: "Tatenda sends most of his money to Zimbabwe to family members and friends he has not seen for years and this leaves us with little to spend". The discussion revealed the multi-layered complexities of transnational lives and it brought some clarity to Tatenda's characterization of himself as "a dislocated person in a discarded place".

\section{Case 3: Kudzi}

Kudzi was a 38 year old University of Zimbabwe graduate and was married, with three children, including a baby who was Swazi by birth. He had, however, travelled to Masvingo (in Zimbabwe) where he got a Zimbabwean birth certificate for the baby. Kudzi used to be a Science teacher at one of the leading secondary schools outside Harare until he resigned in 2008 at the height of the economic crisis in Zimbabwe that was characterized by a general decline of the economy, extensive de-industrialisation, and the collapse of the Zimbabwean dollar. Kudzi joked about the day when he went to a department store to buy a pair of shoes. He said: "I could not buy the pair of shoes because my monthly salary of several trillion Zimbabwean dollars had become too small to pay for a pair of shoes". The next day he boarded a bus to Johannesburg in search of greener pastures. After three months, he secured a job as a Mathematics teacher at a private college in Pretoria. However, he was fired by the college principal six months later after making what he called "an undiplomatic request for equal work and equal pay".

Kudzi arrived in Manzini at the beginning of 2010 soon after he had lost his job in South Africa. He stayed with a distant cousin in Moneni, which is an upgraded former informal settlement in Manzini, while he was looking for a job but has since moved to a middle income suburb called Cotts Valley. Kudzi taught Physics and Mathematics at a small private school in Manzini. His salary was about $80 \%$ of what his Swazi colleagues got despite the fact that he had more years of experience and his students always performed well in the national examinations. In Zimbabwe his family was poor; his retired father had developed health problems and was now dependent on the remittances that he regularly sent home. However, his financial position did not allow him to send money back home regularly for the upkeep of his father and step mother. Despite the great ease with which he settled in Manzini, he had become disillusioned because his efforts to secure employment as a science teacher at one of the government schools in the country had been unsuccessful. Kudzi had plans to relocate to South Africa as soon as he secured a teaching job. 


\section{Case 4: Chenje}

Chenje was 35 years old and married. He had lived in Manzini for two years and his wife had recently joined him from Zimbabwe. He explained that the early days of his stay in Manzini involved considerable frustrations around issues like acquiring documentation to legally enter the Swazi labour market. Chenje stayed with friends and worked as a gardener for three months, despite his diploma in education, before he secured a job as a teacher at a private college in Manzini. The private college offers secondary school tuition and upgrading lessons to students who fail to secure enough points for entry into university or colleges (e.g. Teachers and Technical colleges). His salary was low and variable because it was based on the class size and the size of the monthly tuition fees received by the college. He mentioned that he supplemented his income by "doing odd jobs" during weekends and after working hours. His multiple jobs gave him multiple identities and he had no problems switching from one to the other as the situation dictated. He mentioned that his life was better in Manzini than it had been when he left Zimbabwe and he was likely to remain in Swaziland for "quite some time". He had thought about looking for a teaching job in South Africa but had not yet applied because of his concerns at the time about what he heard to be "high levels of hostility towards outsiders". His cousin who had previously tried his luck as a teacher had gone back to Zimbabwe when the economic situation had started to improve two years ago. Chenje often remarked during the interview, "[...] to make it in Manzini you need patience and lots of energy".

\section{DISCUSSION}

The focus on translocality enables us to understand postcolonial African urbanism where migrants reside in multiple transnational spaces (Smith, 2001). The cultural diversity of Manzini makes the city into a powerful conceptual tool for imagining the transnational interconnectivities that characterise migrants' livelihood pathways that link the home country and their diasporic spaces. The Zimbabwean teachers explained their move to Manzini in terms of strategic economic imperatives. From the point of view of the Zimbabwean migrant teachers, Manzini is a place of negotiation, of encounter and of new creative energies, and also of social exclusion and inclusion. The Zimbabwean teachers in Manzini find themselves caught in shifting and uncomfortable confined spaces between the home country and the host country. As Kudzi, the migrant teacher from Zimbabwe, stated, 
Manzini had failed to be the perfect imagined place for some of the teachers because of the difficulties in securing permanent employment and accommodation in safe neighbourhoods. Portes, Guarnizo and Landolt (1999) have argued that success for migrants depends not only on their ability to embrace another society but also on the capacity to preserve their original cultural endowments while adapting instrumentally to a second. South Africa has always been the preferred destination of Zimbabwean migrants, irrespective of whether they are skilled or not.

All the Zimbabwean migrant teachers spoke about the "otherness" challenges which they had to deal with constantly. Tatenda mentioned that despite having lived in Manzini for over eight years and having married a Swazi wife he was still considered an outsider who did not belong. He found such attitudes quite disturbing and this made his stay in the country difficult because his "foreignness" was always an issue. The reality of life for migrants is the need to make some form of living in order to ensure basic survival. However, this was invariably framed by migrants as another challenge, along with trying to secure a permanent job or somewhere to live.

Zimbabwean social networks both facilitate migration and assist in settlement and survival once people arrive. However, the depth of these networks beyond assistance with housing and jobs was limited. Friends and family were crucial in providing new migrants with initial lodging until they found their own place, as was the case with Chenje and Kudzi discussed above. However, these networks were very limited in size and the Zimbabwean migrant teachers reported having very small friendship circles outside the Zimbabwean community in Swaziland. However, Chenje mentioned that despite being a "go-getter" with many friends outside the Zimbabwean network or the migrant community, he experienced many job related challenges which made him think about his complex relationship with the city of Manzini.

While leaving family and friends has been a stressful experience for most Zimbabwean migrant teachers who were interviewed, the biggest challenge has been presented by the lack of stable employment and situations of illegality regarding access to the labour market in Swaziland. The situation was aggravated by feelings of anxiety, alienation and loneliness and this is why some of the migrant teachers constantly re-imagined Manzini's suitability as an ideal space. Furthermore, according to some of the Zimbabwean teachers, Manzini had not lived up to its reputation as a transnational space and site of new cultural possibilities. As Chenje remarked, Manzini was a 
site where the economic hardships that he had run away from in Zimbabwe were being reproduced all over again.

How they negotiate their stay, whom they associate with, and the strategies they pursue to integrate themselves into Swazi society are some of the key factors that determine the success of migrant teachers' stay in Swaziland. During the in-depth interviews it became apparent that the Zimbabwean migrant teachers were able to maintain a "virtual presence" in Zimbabwe and they considered their stay in Swaziland generally better than the life they had experienced back home.

Most of the Zimbabwean migrant teachers interviewed maintained regular communication with their families and friends back home. Most sent remittances in the form of cash or goods at least once in two months (see Tevera and Chikanda, 2009). Sending money was both a necessity and an obligation that was an integral part of being a migrant in Swaziland. However, while the Zimbabwean teachers derived satisfaction from sending money home it is also essential to recognise the complicated conditions under which they live and work in Manzini in order to be able to send this money. However, most of the Zimbabwean migrant teachers interviewed opted to remain in Swaziland rather than return home because they earned more than they would back home and they preferred to use their diasporic remittances to provide social protection "grants" to their families.

Locals in Swaziland commonly refer to foreigners as Makwerekwere which is a term that refers to their non-belonging and they are imagined and treated as "others". This finding mirrors that of Manik (2013: 81) who observed that Zimbabwean immigrant teachers in KwaZulu-Natal, South Africa were often "viewed with the same disdain and attitudes shown to illegal immigrants". This article has highlighted the degree of empowerment (through social networking) and disempowerment (under pay at the work place and failure to secure permanent employment) that Zimbabwean migrant teachers experienced as they grappled with issues of shifting family relationships and responsibilities in response to their transnational realities that are characterised by spatial and temporal separations. Some Zimbabwean migrant teachers in Manzini managed to be part of nurturing and supportive local and transnational networks and have made the process of adjusting to day-to-day challenges in Manzini a little easier. However, most of these networks have tended to be informal migrant networks comprising of their Zimbabwean compatriots. Sibongile was one of the few Zimbabwean migrant teachers who belonged to multiple networks involving locals 
and migrants from other countries. For example, most of the Zimbabwean migrant teachers who were interviewed would have wanted to be engaged in such networks because these constitute a powerful transcultural capital that is rewarding in socio-cultural and economic terms.

\section{CONCLUSION}

This paper contributes to the recent academic debate on South-South experiences of highly skilled migrants by exploring how Zimbabwean migrant teachers interviewed were remaking their lives in the urban transnational space of Manzini. The study provides insights into the transnationalised experiences of the teachers as they grappled with challenges around issues of "belonging" and "not belonging". The teachers thought a lot about their complicated status in Manzini and one of them characterized it as a "compromised citizenship". The teachers also talked about their aspirations to maintain a "virtual presence" through internet links, Skype calls and remittance flows back home. This paper focused on the "production of emigration" (i.e. the reasons why the Zimbabwean migrant teachers in Manzini left their homes) and the "problems of integration" (i.e. the labour related and adjustment challenges they faced in Swaziland). Clearly, each migration move by the teachers should be viewed as a personal response to specific issues around structure and agency. The interviews captured the voices of the migrant teachers and revealed how their transnationalised lives reflected complex constructions of their migrant subjectivities. The study revealed that while some of the Zimbabwean migrant teachers in Swaziland imagined Manzini as a tough economic space, most, however, had resolved to remain in the city because their residence made it possible for them to support their families back home. Also, their experiences in Swaziland involved considerable frustrations, especially around issues like getting suitable employment, exploitation at the workplace, and the lack of job security. Despite these challenges, the teachers were able to meet their financial commitments and still send cash remittances back home. 
Acknowledgments: The author is grateful to all the Zimbabwean migrant teachers who participated in the project. The fieldwork was carried out at the time when the author was Professor in the Department of Geography, Environmental Science and Planning at the University of Swaziland. The author would also like to thank the two anonymous reviewers for their valuable comments.

\section{REFERENCES}

Adepoju, A. (2006). Leading Issues in International Migration in Sub-Saharan Africa, in: C. Cross et al. (eds). Views on Migration in Sub-Saharan Africa. Pretoria: HRSC press, 25-47.

Al-Ali, N., Black, R. and Koser, K. (2001). The limits to "transnationalism": Bosnian and Eritrean refugees in Europe as emerging transnational communities, Ethnic and Racial Studies, 24 (4): 578-600, doi: 10.1080/01419870120049798.

Bailey, A. J. (2001). Turning transnational: notes on the theorisation of international migration, International Journal of Population Geography, 7 (6): 413-428, doi: 10.1002/ ijpg.239.

Blunt, A. (2007). Cultural geographies of migration: mobility, transnationality and diaspora, Progress in Human Geography, 31 (5): 684-694, doi: 10.1177/0309132507078945.

Boyd, M. (1989). Family and Personal Networks in International Migration: Recent Developments and New Agendas, International Migration Review, 23 (3): 638-670, doi: $10.2307 / 2546433$.

Campbell, E. (2001). Preferences for emigration among skilled citizens in Botswana, International Journal of Population Geography, 7 (3): 151-171, doi: 10.1002/ijpg.216.

Conradson, D. and Latham, A. (2005). Transnational Urbanism: Attending to Everyday Practices and Mobilities, Ethnic and Migration Studies, 31 (2): 227-233, doi: 10.1080/1369183042000339891.

Crush, J. and Tevera, D. S. (eds) (2010a). Zimbabwe's Exodus: Crisis, Migration and Survival. Cape Town - Ottawa: Southern African Migration Programme - IDRC.

Crush, J. and Tevera, D. S. (2010b). Discontent and Departure: Attitudes of Skilled Zimbabweans Towards Emigration, in: J. Crush and D. S. Tevera (eds). Zimbabwe's Exodus: Crisis, Migration and Survival. Cape Town - Ottawa: Southern African Migration Programme - IDRC, 112-130.

Faist, T. (2000). Transnationalization in international migration: implications for the study of citizenship and culture, Ethnic and Racial Studies, 23 (2): 189-222, doi: 10.1080/014198700329024.

Glick Schiller, N., Basch, L. and Blanc-Szanton, C. (eds) (1992). Towards a Transnational Perspective on Migration: Race, Class, Ethnicity and Nationalism Reconsidered. New York: New York Academy of Science.

Hammar, A., McGregor, J. and Landau, L. (2010). Introduction: Displacing Zimbabwe: Crisis and construction in Southern Africa, Journal of Southern African Studies, 36 (2): 263-283, doi: 10.1080/03057070.2010.485779. 
Kelly, P. and Lusis, T. (2006). Migration and the transnational habitus: evidence from Canada and the Philippines, Environment and Planning A, 38 (5): 831-847, doi: 10.1068/a37214.

Kivisto, P. (2001). Theorizing transnational immigration: a critical review of current efforts, Ethnic and Racial Studies, 24 (3): 549-577, doi: 10.1080/01419870120049789.

Kriger, N. (2010). The politics of legal status for Zimbabweans in South Africa, in: J. McGregor and R. Primorac (eds). Zimbabwe's New Diaspora: Displacement and the Cultural Politics of Survival. Oxford: Berghahn Books, 77-100.

Landolt, P. (2001). Salvadoran economic transnationalism: embedded strategies for household maintenance, immigrant incorporation, and entrepreneurial expansion, Global Networks, 1 (3): 217-242, doi: 10.1111/1471-0374.00014.

Lawson, V. A. (2000). Arguments within geographies of movement: the theoretical potential of migrants' stories, Progress in Human Geography, 24 (2): 173-189, doi: 10.1191/030913200672491184.

Levitt, P., Dewind, J. and Vertovec, S. (2003). International perspectives on transnational migration: an introduction, International Migration Review, 37 (3): 565-575, doi: 10.1111/j.1747-7379.2003.tb00150.x.

Manik, S. (2009). Understanding the Exit of Teachers from South Africa: Determinants of Transnational Teacher Migration, Perspectives in Education, 27 (3): 267-277.

Manik, S. (2013). Zimbabwean Immigrant Teachers in KwaZulu-Natal Count the Cost of Going under the Hammer, Alternation: Special Edition, 20 (7): 67-87.

Morapedi, W. (2007). Post-liberation xenophobia in southern Africa: the case of the influx of undocumented Zimbabwean immigrants into Botswana, c. 1995-2004, Journal of Contemporary African Studies, 25 (2): 229-250, doi: 10.1080/02589000701396330.

Morris, A. (1998). "Our fellow Africans make our lives hell”: the lives of Congolese and Nigerians living in Johannesburg, Ethnic and Racial Studies, 21 (6): 1116-1136, doi: 10.1080/01419879808565655.

Nolin, C. (2002). Transnational ruptures and sutures: questions of identity and social relations among Guatemalans in Canada, GeoJournal, 56 (1): 59-67, doi: 10.1023/a:1021709019790.

Oucho, J. (2000). Skilled migrants in Botswana, Africa Insight, 30 (2): 56-64.

Portes, A. (2003). Conclusion: Theoretical Convergencies and Empirical Evidence in the Study of Immigrant Transnationalism, International Migration Review, 37 (3): 874-892, doi: 10.1111/j.1747-7379.2003.tb00161.x.

Portes, A., Guarnizo, L. E. and Landolt, P. (1999). The study of transnationalism: pitfalls and promise of an emergent research field, Ethnic and Racial Studies, 22 (2): 217-237, doi: 10.1080/014198799329468.

Silvey, R. (2006). Consuming the transnational family: Indonesian migrant domestic workers to Saudi Arabia, Global Networks, 6 (1): 23-40, doi: 10.1111/j.14710374.2006.00131.x.

Silvey R. and Lawson, V. (1999). Placing the migrant, Annals of the Association of American Geographers, 89 (1): 121-132, doi: 10.1111/0004-5608.00134.

Smith, M. P. (2001). Transnational Urbanism: Locating Globalization. Oxford: Blackwell.

Tevera, D. S. (2011). Migration and Development in Swaziland, UNISWA Research Journal, 26: 15-27. 
Tevera, D. S. (2013). African Migrants, Xenophobia and Urban Violence in Post-Apartheid South Africa, Alternation: Special Issue, 20 (7): 9-26.

Tevera, D. S. and Chikanda, A. (2009). Development Impact of International Remittances: Some Evidence from Origin Households in Zimbabwe, Global Development Studies, 5 (3-4): 274-302.

Tevera, D. S. and Crush, J. (2010). Exiting Zimbabwe, in: J. Crush and D. S. Tevera (eds). Zimbabwe's Exodus: Crisis, Migration and Survival. Cape Town - Ottawa: Southern African Migration Programme - IDRC, 1-49.

Worby, E. (2010). Address Unknown: the Temporality of Displacement and the Ethics of Disconnection among Zimbabwean Migrants in Johannesburg, Journal of Southern African Studies, 36 (2): 417-431, doi: 10.1080/03057070.2010.485792. 


\section{Ponovno stvaranje života u transnacionalnome urbanom prostoru: zimbabveanski učitelji migranti u Manziniju u Svaziju}

\section{Daniel Tevera}

\section{SAŽETAK}

Nedavna intelektualna rasprava o transnacionaliziranim životima kvalificiranih migranata iz zemalja u razvoju nastoji pružiti opće primjenjiva objašnjenja, koja često ne uzimaju u obzir pozadinske socio-ekonomske kontekste. Svrha je ovoga rada pridonijeti raspravi istraživanjem kako kvalificirani migranti u južno-južnim dijasporskim situacijama, budući da djeluju u transnacionalnim prostorima, iznova stvaraju svoje strategije zarađivanja za život i očekivanja. Rad se temelji na terenskom istraživanju koje uključuje dubinske intervjue sa zimbabveanskim učiteljima migrantima koji žive u Manziniju, trgovačkom središtu Svazija. Istraživanje pruža uvid u složene i transnacionalizirane strategije prilagodbe koje migranti primjenjuju hvatajući se u koštac s izazovima uključivanja i isključivanja u zemlji primitka i održavanjem »virtualne prisutnosti $u \mathrm{u}$ svojoj domovini Zimbabveu internetom, Skypeom, mobilnim telefonima i pošiljkama.

KLJUČNE RIJEČI: transnacionalizam, virtualna prisutnost, uključivanje, isključivanje, oživljavanje ksenofobije, migranti, Manzini 